\title{
Modeling of structural effects in biomedical elements after titanium oxidation in fluidized bed
}

\author{
J. Jasiński, M. Szota ${ }^{1}$, K. Mendzik \\ Czestochowa University of Technology, \\ 1Faculty of Materials Processing Technology and Applied Physics, \\ Materials Engineering Institute, \\ Biomaterials and Surface Layer Research Institute, \\ Av. Armii Krajowej 19, 42-200 Czestochowa, Poland
}

\begin{abstract}
Oxidation is one of the most employed methods to improve titanium and its alloys properties especially due to medical application. This process like most of the thermochemical treatment processes substantially influences on the characteristic of surface layers and the same on its mechanical and useful properties. Oxide coatings produced during titanium oxidation were examined due to their composition identification. Titanium was oxidized in fluidized bed in temperature range between $500 \div 700^{\circ} \mathrm{C}$. Microstructures of titanium with a visible oxide coating on its surface after thermochemical treatment and changes of grain size in core of titanium samples are described. Moreover Xray phase analysis of obtained oxides coatings was made as well as microhardness measurements of titanium surface layers after oxidation process. Finally, the surfaces of titanium after oxidation in fluidized bed were measured by Auger electron spectroscopy. All research results are used to built numerical model of oxidation process in fluidized. Titanium oxidation process in fluidized bed is very complicated, because changes of parameters are non linear characteristics. This fact and lack of mathematical algorithms describing this process makes modeling properties of titanium elements by traditional numerical methods difficult or even impossible. In this case it is possible to try using artificial neural network. Using neural networks for modeling oxidizing in fluidized bed is caused by several nets' features: non linear character, ability to generalize the results of calculations for data out of training set, no need for mathematical algorithms describing influence changes input parameters on modeling materials properties.
\end{abstract}

\section{Keywords:}

Titanium; Oxidation; Fluidized bed; Neural network; Biomaterials

1 e-mail: mszota@mim.pcz.czest.pl

This is an Open Access article distributed under the terms of the Creative Commons Attribution-Noncommercial License 3.0, which permits unrestricted use, distribution, and reproduction in any noncommercial medium, provided the original work is properly cited. 


\section{Introduction}

In last years technical progress caused that materials, which are used in constructions, must be changed for more prospective and useful materials. Very often requirements for construction materials are high strength with low weight, as well as good corrosion resistance in very aggressive environments. At the same time biomedicine is intensively developing in the field of reconstruction of damaged anatomical structures, and after it goes a need of searching new, better biomaterials, among other things for implants [1], or improving methods to receive better properties of known in this field materials [2]. Secondary hip joint arthroplasty needs the massive and frozen bone grafts and metal stabilizers in the form of nets and baskets, which strengthen and fasten the bone defects [3]. Stabilizers protect the graft against excessive overload occurring in its surrounding, especially during heal process [4]. These elements are working in very aggressive environment, which is human body, and they should have good corrosion resistance and biocompatibility, what can be bettered by using proper heat treatment.

One of the new methods of improving increasing corrosion resistance and tribological properties is surface hardening of implants by oxidation.

High oxygen affinity to titanium makes that this material is very easy, even at room temperature, covered with oxide coat $\left(\mathrm{TiO}_{2}\right)$, which is stable and very adherent to the surface, however the coating is very thin. At high temperatures titanium oxidizes very fast, and it results in thicker, but often porous or cracked and not enough adherent to the surface oxide layer. The trend is to combine advantages of high and low temperature oxidizing of titanium using for that reason various treatment methods.

\section{Literature}

1 D. Kuroda, M. Niinomi, M. Morinaga, Y. Kato, T. Yashiro; Design and mechanical properties of $\beta$ type titanium alloys for implant materials, Materials Science and Engineering A 243, (1998), p. $244 \div 249$

2 M.C. GarciaAlonso, L. Saldaña, G. Valles, J.L. Gonzalez-Carrasco, J. Gonzalez-Cabrero, M.E. Martinez, E. Gil-Garay, L. Munuera; In vitro corrosion behaviour and osteoblast response of

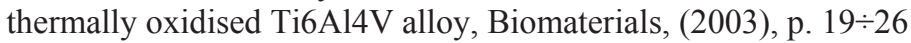

3 B. Wójcik, J. Jasiński, B. Stodolnik, L. Jeziorski, M. Lubas, T. Gaździk: System stabilizacji przeszczepu kostnego allogenicznego w protezoplastyce rekonstrukcyjnej i rewizyjnej panewek endoprotez stawu biodrowego, Engineering of Biomaterials 28, (2003)

4 Gaździk T., Wójcik B., Niedźwiedzki Ł., Dec J.: Wymiana aseptycznie obluzowanych panewek cementowych stawu biodrowego, Chir. Nrz. Ruchu Ort. Pol., 2002-67(2) allogenicznego w protezoplastyce rekonstrukcyjnej i rewizyjnej panewek endoprotez stawu biodrowego, Engineering of Biomaterials, 28, (2003)

5 F. Borgioli, E. Galvanetto, F.P. Galliano, T. Bacci; Air treatment of pure titanium by furnace and glow-discharge processes, Surface and Coatings Technology 141, 2001, 103 $\div 107$. 